\title{
Olhar para trás, olhar para a frente
}

RUI PINA COELHO

Durante dez anos, de 2004 a 2014, a cada seis meses, em Junho e Dezembro, sem interrupções, publicámos - a Associação Portuguesa de Críticos de Teatro (APCT) e o Centro de Estudos de Teatro da Faculdade de Letras da Universidade de Lisboa (CET) - a revista Sinais de Cena. Habituámo-nos a esta vida sazonal, com as (aparentemente) infindáveis maratonas de traduções, revisões, recolha, selecção e legendagem de imagens e outras aflições de vária natureza. Não foram anos fáceis. Foi necessária muita persistência e determinação para manter uma publicação especializada em teatro durante tanto tempo, num país em que objectos semelhantes parecem ter sempre vida curta. Não foram mesmo anos fáceis... Pelo caminho fomos perdendo muitos amigos, elementos fundamentais na dinâmica da revista e na revitalização da APCT: Carlos Porto, Luiz Francisco Rebello, Paulo Eduardo Carvalho. Fomos, felizmente, também encontrando muitos companheiros novos que se foram entusiasmando com a nossa teimosia. As páginas da nossa revista foram sempre palco de convívio e de partilha fraterna entre críticos mais experientes e outros mais jovens, fazendo da Sinais de Cena um autêntico colégio para a crítica de teatro em Portugal.

Maria Helena Serôdio, que, incansavelmente, dirigiu a revista nesses dez anos, soube sempre animar-nos e fazer-nos avançar, mesmo quando parecia manifestamente impossível continuar o projecto. Foram dez anos de que nos orgulhamos até ao embaraço. Contudo, em Dezembro de 2014, após um inqualificável processo de avaliação às unidades de investigação científica em Portugal, deixou de ser possível ao CET continuar a apoiar a edição da revista, razão pela qual decidimos pôr um ponto final na nossa aventura.

O tempo, porém, transformou esse ponto final em reticências e começamos agora, com este número, uma nova série da revista. Não obstante manter uma lógica de continuidade com o projecto editorial inicial, haverá algumas alterações de monta, nomeadamente: periodicidade anual; arbitragem científica; quatro línguas de trabalho: português, espanhol, francês e 
inglês. Assim, haverá duas secções com arbitragem científica: (o «Dossiê Temático» e os «Estudos Aplicados»). As restantes secções manter-se-ão como na série I, desaparecendo, contudo, «Em Rede», «Notícias de Fora»e «Arquivo Solto». Esta ausência não significará que o mundo digital, o teatro internacional e a historiografia irão ser apagados das páginas da revista, mas sim que estes tópicos aparecerão integrados e diluídos nas restantes secções. Manter-se-ão, portanto, as que se seguem: «Na Primeira Pessoa» (entrevista de longo fôlego a um artista); «Leituras» (dedicada à recensão de textos de ou sobre teatro); «Portefólio», secção exclusivamente dedicada à representação iconográfica teatral, onde se publicam conjuntos extensivos de fotografias sobre um dramaturgo, uma companhia, um festival ou um fotógrafo em particular; e, claro, «Passos em Volta», que acolhe críticas de teatro e outras artes performativas.

Neste primeiro número da série II da Sinais de Cena, começamos também uma nova teia de cumplicidades, ao mesmo tempo que renovamos algumas antigas e já sólidas. Assim, nesta segunda vida contamos com o apoio da Direcção da Faculdade de Letras da Universidade de Lisboa e, através de publicidade institucional regular, das Direcções do Teatro Nacional D. Maria II de Lisboa e do Teatro Nacional São João do Porto, prolongando ao longo dos anos o seu voto de confiança em nós. Sem estes apoios seria absolutamente impossível continuarmos o projecto da Sinais de Cena. No que diz respeito à identidade gráfica da revista e à edição, também haverá uma importante alteração: sairemos em parceria com a prestigiada Orfeu Negro, editora que nos permite diálogos construtivos, pondo ao nosso dispor contribuições e conselhos de inestimável valor.

A Sinais de Cena passará, pois, a integrar um dos catálogos mais estimulantes e actualizados na área dos estudos de teatro e das artes performativas em Portugal, chegando a muitos mais leitores, que nem sempre a ela tinham acesso.

$\mathrm{O}$ «Dossiê Temático» deste número é dedicado ao tema «Teatro e Memória», em grande medida devido ao nosso entusiasmo com o espectáculo Um Museu Vivo de Memórias Pequenas e Esquecidas, de Joana Craveiro/Teatro do Vestido. Trata-se de um espectáculo-palestra que reúne sete lições sobre o Portugal da Revolução de Abril, construído de modo a reexaminar o Portugal dos séculos XX e XXI, 
convidando a analisar o país em que nos tornámos. Assim, este trabalho é aqui interpelado criticamente por Marta Lança, que se serve do trabalho de Craveiro para discutir processos de construção da memória, e por Daniele Ávila Small, que inquire a relação entre o teatro e a história na actualidade a partir deste espectáculo e de Guerrilheiras ou Para a Terra não Há Desaparecidos, um projecto da actriz Gabriela Carneiro da Cunha, do Rio de Janeiro. Convidámos também a própria criadora, Joana Craveiro, para nos deixar uma reflexão sobre as operações de composição do espectáculo e os estudos de Memória, sua área de especialização académica.

Mas o nosso empolgamento serve-nos também para ampliarmos a discussão em torno das noções de Teatro e Memória, termos provavelmente indissociáveis, laborando em torno dos universos do teatro documentário, do teatro do real, do docudrama, do teatro verbatim, ou, em suma, discutindo a alegada irrupção do real na criação contemporânea.

Assim, Carol Martin, importante referência para o estudo desta área, prolonga alguns dos argumentos apresentados em Dramaturgy of the Real on the World Stage (2010) e Theatre of the Real (2013), discutindo três trabalhos que abordam e criticam as epistemologias da memória ao misturarem livremente as suas fontes de maneiras provocadoras: The Circuit, o Heidelberg Project e Hamlet/Ur-Hamlet; e José da Costa investiga a presença e a memória a propósito da peça-biografia sobre a actriz brasileira Cacilda Becker, encenada por José Celso Martinez Corrêa, no Teatro Oficina (1998).

Nos «Estudos Aplicados», secção de ensaios sem unidade temática precisa, Anabela Mendes torna ao espanto que Woyzeck, de Büchner, continua a exercer em nós; José Sasportes dá conta dos olhares preceptivos sobre a dança ao longo dos séculos; Françoise Decroisette regressa à commedia dell'arte e à memória de Scapin; Nicolás Barbosa apresenta um estudo raro sobre $O$ Marinheiro, de Fernando Pessoa; e Maria João Brilhante discorre sobre desafios e contingências de pôr em cena A Vida de D. Quixote de La Mancha e do Gordo Sancho Pança, de António José da Silva, através da análise de dois espectáculos, pela Comédie-Française e pela companhia de teatro $\mathrm{O}$ Bando.

Nas «Leituras», Ana Isabel Vasconcelos recenseia Sete Olhares sobre o Teatro da Nação, uma obra coordenada por Maria João Brilhante para o Teatro Nacional D. Maria II; Christine Zurbach apresenta Fresco Bruegeliano, o importante estudo sobre 
dramaturgia portuguesa da autoria de António Conde; Ana Campos apresenta, de forma apaixonada, Os Belos Dias de Aranjuez: Um diálogo de Verão, de Peter Handke; e Emília Costa faz uma radiografia precisa do Teatro Reunido, de Carlos Alberto Machado, publicado pela Companhia das Ilhas. Ainda nas «Leituras», Sebastiana Fadda apresenta, como de costume e na sequência da Sinais de Cena n. ${ }^{\circ} 21$ da I série, a lista de publicações de e sobre teatro saídas em 2014 e 2015, mais as adendas respeitantes a anos anteriores.

Não obstante o seu pendor tendencialmente académico, os ensaios críticos a espectáculos de teatro e de outras artes performativas continuarão a ser parte estruturante da Sinais de Cena. Deste modo, neste número, Gustavo Vicente continua a discussão em torno de Um Museu Vivo, de Joana Craveiro; Emília Costa examina Your Best Guess, da Mala Voadora; Eunice Tudela de Azevedo, Rui Pina Coelho e José Pedro Serra oferecem três abordagens à trilogia trágica de Tiago Rodrigues apresentada no Teatro Nacional D. Maria II; Bruno Schiappa reflecte sobre o ciclo Recém-Nascidos, mostrado nesse mesmo teatro; Catarina Firmo dá conta da edição de 2015 do Festival Internacional de Marionetas do Porto; José Pedro Sousa traduz criticamente o seu entusiasmo pelo Ricardo III, de Tónan Quito; e Ana Pais relata uma das suas viagens pelo teatro nova-iorquino, apresentando o novo espectáculo dos Elevator Repair Service «e outras experiências off».

Desta vez, a entrevista é feita a uma das mais originais pesquisadoras artísticas nacionais, Mónica Calle, que, entrevistada por Maria João Brilhante, Eunice Tudela de Azevedo e Gustavo Vicente, regressa às matrizes temáticas do seu percurso artístico, desfiando, em particular, as preocupações estéticas e sociais que têm pautado os seus últimos anos de actividade.

E, no «Portefólio», num trabalho coordenado por Filipe Figueiredo e Paula Magalhães, apresentamos um conjunto impressivo de fotografias de espectáculo de um dos mais proficientes fotógrafos da cena nacional, Pedro Soares, deixando aqui um nostálgico olhar sobre o teatro português desde o início da década de 1980 .

E é assim que retomamos caminho. 